\title{
Chondrogenic differentiation of adipose-derived mesenchymal stem cells induced by L-ascorbic acid and platelet rich plasma on silk fibroin scaffold
}

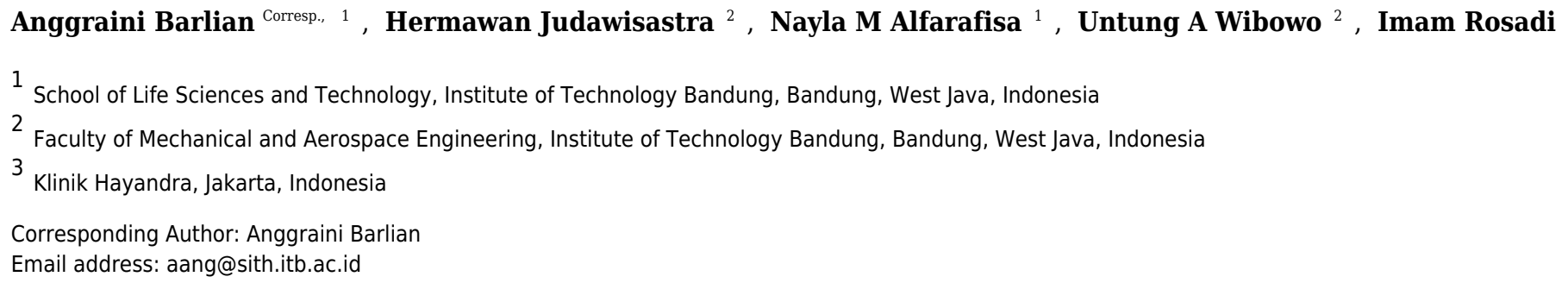

Articular cartilage is an avascular tissue with limited regenerative property. Therefore, a defect or trauma in articular cartilage due to disease or accident can lead to progressive tissue deterioration. Cartilage tissue engineering, by replacing defective cartilage tissue, is a method for repairing such a problem. In this research, three main aspects-- cell, biomaterial scaffold, and bioactive factors--that support tissue engineering study were optimized. Adipose-derived mesenchymal stem cells (ADSC) that become cartilage were grown in an optimized growth medium supplemented with either platelet rich plasma (PRP) or L-ascorbic acid (LAA). As the characterization result, the ADSC used in this experiment could be classified as Mesenchymal Stem Cell (MSC) based on multipotency analysis and cell surface marker analysis. The biomaterial scaffold was fabricated from the Bombyx morii cocoon using silk fibroin by salt leaching method and was engineered to form different sizes of pores to provide optimized support for cell adhesion and growth. Biocompatibility and cytotoxicity evaluation was done using MTT assay to optimize silk fibroin concentration and pore size. Characterized ADSC were grown on the optimized scaffold.LAA and PRP were chosen as bioactive factors to induce ADSC differentiation to become chondrocytes. The concentration optimization of LAA and PRP was analyzed by cell proliferation using MTT assay and chondrogenic differentiation by measuring glycosaminoglycan (GAG) using Alcian Blue at $605 \mathrm{~nm}$ wavelength. The optimum silk fibroin concentration, pore size, LAA concentration, and PRP concentration were used to grow and differentiate characterized ADSC for 7, 14, and 21 days. The cell morphology on the scaffold was analyzed using a scanning electron microscope (SEM). The result showed that the ADSC could adhere on plastic, express specific cell surface markers (CD73, CD90, dan CD105), and could be differentiated into three types of mature cells. The silk fibroin scaffold made from $12 \% \mathrm{w} / \mathrm{v}$ concentration formed a $500 \mu \mathrm{m}$ pore diameter (SEM analysis), 
and was shown by MTT assay to be biocompatible and to facilitate cell growth. The optimum concentrations of the bioactive factors LAA and PRP were $50 \mu \mathrm{g} / \mathrm{mL}$ and $10 \%$, respectively. GAG analysis with Alcian Blue staining suggested that PRP induction medium and LAA induction medium on $12 \% \mathrm{w} / \mathrm{v}$ scaffold could effectively promote not only cell adhesion and cell proliferation but also chondrogenic differentiation of ADSC within 21 days of culture. Therefore, this study provides a new approach to articular tissue engineering with a combination of ADSC as cell source, LAA and PRP as bioactive factors, and silk fibroin as a biocompatible and biodegradable scaffold. 
1 Chondrogenic differentiation of adipose-derived mesenchymal stem cells induced by l-

2 ascorbic acid and platelet rich plasma on silk fibroin scaffold

3 Anggraini Barlian', Hermawan Judawisastra², Nayla M. Alfarafisa1, Untung A. Wibowo ${ }^{2}$,

4 Imam Rosadi ${ }^{3}$,

$5{ }^{1}$ School of Life Sciences and Technology Institut Teknologi Bandung Jalan Ganesha 10,

6 Bandung, Indonesia

$7 \quad{ }^{2}$ Faculty of Mechanical and Aerospace Engineering Institut Teknologi Bandung Jalan Ganesha

8 10, Bandung, Indonesia

$9 \quad{ }^{3}$ Klinik Hayandra, Jalan Kramat 6 no. 11, Jakarta, Indonesia

*Correspondence should be addressed to A.B.

10 E-mail: aang@sith.itb.ac.id

\section{ABSTRACT}

Articular cartilage is an avascular tissue with limited regenerative property. Therefore, a defect or trauma in articular cartilage due to disease or accident can lead to progressive tissue deterioration. Cartilage tissue engineering, by replacing defective cartilage tissue, is a method for repairing such a problem. In this research, three main aspects-- cell, biomaterial scaffold, and bioactive factors--that support tissue engineering study were optimized. Adipose-derived mesenchymal stem cells (ADSC) that become cartilage were grown in an optimized growth medium supplemented with either platelet rich plasma (PRP) or L-ascorbic acid (LAA). As the characterization result, the ADSC used in this experiment could be classified as Mesenchymal Stem Cell (MSC) based on multipotency analysis and cell surface marker analysis. The biomaterial scaffold was fabricated from the Bombyx morii cocoon using silk fibroin by salt leaching method and was engineered to form different sizes of pores to provide optimized support for cell adhesion and growth. Biocompatibility and cytotoxicity evaluation was done using MTT assay to optimize silk fibroin concentration and pore size. Characterized ADSC were grown on the optimized scaffold.LAA and PRP were chosen as bioactive factors to induce ADSC differentiation to become chondrocytes. The concentration optimization of 
27 LAA and PRP was analyzed by cell proliferation using MTT assay and chondrogenic 28 differentiation by measuring glycosaminoglycan (GAG) using Alcian Blue at 605nm 29 wavelength. The optimum silk fibroin concentration, pore size, LAA concentration, and PRP 30 concentration were used to grow and differentiate characterized ADSC for 7, 14, and 21 days. 31 The cell morphology on the scaffold was analyzed using a scanning electron microscope 32 (SEM). The result showed that the ADSC could adhere on plastic, express specific cell 33 surface markers (CD73, CD90, dan CD105), and could be differentiated into three types of 34 mature cells. The silk fibroin scaffold made from $12 \% \mathrm{w} / \mathrm{v}$ concentration formed a $500 \mu \mathrm{m}$ 35 pore diameter (SEM analysis), and was shown by MTT assay to be biocompatible and to 36 facilitate cell growth. The optimum concentrations of the bioactive factors LAA and PRP 37 were $50 \mu \mathrm{g} / \mathrm{mL}$ and $10 \%$, respectively. GAG analysis with Alcian Blue staining suggested that 38 PRP induction medium and LAA induction medium on $12 \% \mathrm{w} / \mathrm{v}$ scaffold could effectively 39 promote not only cell adhesion and cell proliferation but also chondrogenic differentiation of 40 ADSC within 21 days of culture. Therefore, this study provides a new approach to articular 41 tissue engineering with a combination of ADSC as cell source, LAA and PRP as bioactive 42 factors, and silk fibroin as a biocompatible and biodegradable scaffold. 
43

44

\section{INTRODUCTION}

Unlike other connective tissues, articular cartilage is an avascular tissue which lacks a nervous and lymphatic system (Zhang, Hu \& Athanasiou 2009). This unique property make it difficult for the cartilage to regenerate tissue after being damaged. Following disease, its structure tends to degrade progressively (Hunziker 2002). The absence of blood supply may also inhibit the wound healing process (Baugé \& Boumédiene 2015), leading to necrosis (Mason et al. 2000), consequently causing a permanent defect in the area. Some methods have been established to treat patients with cartilage tissue defects, such as microfracture, autologus implantation, autograft, allograft, and joint replacement (Zhang, Hu \& Athanasiou 2009); however, these methods have some disadvantages and cause side effects.

Tissue engineering is promising for creating new cartilage tissue that is expected to become functional and ready to be implanted to replace damaged cartilage tissue. Four main parameters support the success of articular cartilage tissue engineering: cell type, growth factors or bioactive factors, mechanical stimuli, and scaffold material (Kock, Donkelaar \& Ito 2012).

The cell source for tissue engineering can be obtained from several tissues or organs, one of which is adipose tissue. Adipose-derived mesenchymal stem cells (ADSC) are mesenchymal stem cells (MSC) obtained from perivascular white adipose tissue, including subcutaneous adipose tissue (Kishi, Imanishi \& Ohara 2010). The isolation of ADSC is relatively easy and produces a higher yield of cells compared to other adult stem cell source tissues (Johnstone et al. 2013).

Bioactive factors used in tissue engineering control cell proliferation and differentiation (Brochhausen et al. 2009); In their study, L-ascorbic acid (LAA) and platelet rich plasma (PRP) were used as bioactive factors for chondrogenic differentiation of ADSC. Temu et al. (2010) showed that LAA could induce the differentiation of a ATDC5 cell line to chondrocytes. 
67 Moreover, LAA can regulate adult stem cell differentiation to some mesenchymal tissues 68 derivatives, such as adipocytes, osteocytes, myocytes, and chondrocytes (Choi et al. 2008). LAA

69 70 has a role as co-factor in post-translational modification of collagen molecules (Gessin et al. 1991), which is a component of the extracellular matrix (ECM) of chondrocytes. Previous study had shown that PRP could be a good candidate for a bioactive factor due to its composition, such as transforming growth factor- $\beta 1$ (TGF- $\beta 1$ ), platelet-derived growth factor (PDGF), epidermal growth factor (EGF), insulin-like growth factor-1 (IGF-1), and vascular endhotelial growth factor (VEGF) that are important for cell differentiation and proliferation (Pawitan et al. 2014). Moreover, PRP had been shown to stimulate cell proliferation and matrix biosynthesis of mammalian chondrocytes as well as the expression of a chondrogenic marker in a MSC 3D culture (Akeda et al. 2006); (Drenk et al. 2009).

The objective of this research was to induce ADSC differentiation to become chondrocytes which were seeded on silk fibroin scaffolds in a PRP induction medium and a LAA induction medium. Silk fibroin was chosen as the biomaterial of the scaffold because it is biodegradable and biocompatible (Wang et al. 2006).

\section{MATERIALS AND METHODS}

\section{Silk Fibroin Scaffold Fabrication}

We used silk fibroin fabricated using a salt leaching method as the scaffolds, as previously characterized by Judawisastra and Wibowo (2017). The silk fibroin was obtained from a Bombyx mori cocoon that was degummed to remove sericin protein which can cause biocompatibility and hypersensitivity problems in vivo (Altman et al. 2003). The cocoon was cut and immersed in $0.05 \% \mathrm{Na}_{2} \mathrm{CO}_{3}$ solution for 1 hour. The cocoon was washed in deionized water to remove residual $\mathrm{Na}_{2} \mathrm{CO}_{3}$ solution and then dried in a fume hood overnight.

Dried silk fibroin was diluted in $8 \mathrm{wt} \% \mathrm{CaCl}_{2}$-Formic acid solution at room temperature with constant stirring for 15-30 minutes. The silk fibroin concentration was optimized by the addition of $6 \mathrm{gr}, 8 \mathrm{gr}, 10 \mathrm{gr}$, and $12 \mathrm{gr}$ silk fibroin into $8 \mathrm{wt} \% \mathrm{CaCl}_{2}$-Formic acid solution. $\mathrm{NaCl}$ with a specific particle size was added into the fibroin solution and homogenized. The $\mathrm{NaCl}$ particle size was important because the scaffold pore size was determined by it. The optimization of pore size to support ADSC proliferation was performed using MTT assay for 100, 300, and $500 \mu \mathrm{m}$ 
96 pore size on days 1, 3, 5, 7, and 14. Data were taken in triplicate for each scaffold on each 97 observational day. The ratio of $\mathrm{NaCl}$ and fibroin solution was 5:1, and then the mixture was dried in the fume hood overnight. The mixture was immersed in a $70 \%$ alcohol solution for \pm 30 minutes to induce $\beta$-sheet formation (Terada et al. 2016), and then the fibroin was immersed in distilled water for 3 days to remove salt residues. Successfully obtained silk fibroin was stored at $-80^{\circ} \mathrm{C}$ for 30 minutes for easier cutting. Before further analysis, th silk fibroin was sterilized using an autoclave for $15-20$ minutes at $121^{\circ} \mathrm{C}$ (Sommer et al. 2016).

\section{Adipose-Derived Stem Cells (ADSC) Isolation and Culture}

The ADSC was obtained from human adipose tissue with ethical approval (No. Reg. 0417060790) from The Health Research Ethics Committee from the Faculty of Medicine, Padjajaran University. The ADSC isolation method followed that of Remelia et al. (2016). Adipose tissue was processed enzymatically using H-Remedy recombinant enzyme which was added to adipose tissue in $10 \% \mathrm{v} / \mathrm{v}$ concentration, and then incubated at $37^{\circ} \mathrm{C}$ for 1 hour. After 1 hour, the growth medium Dulbecco's Modified Eagle's Medium (DMEM) low glucose (1 g/L) (Sigma)and L-glutamin $(4 \mathrm{mM})$ were added to the sample to inactivate enzymes. Then, the sample was centrifuged for 5 minutes with $600 \mathrm{~g}$. The supernatant was discarded, and a $10 \mathrm{~mL}$ red blood cell lysis buffer was added into the pellet and incubated for 5 minutes at room temperature. The sample was centrifuged for 10 minutes at $600_{\mathrm{g}}$ and the supernatant was then discarded. The pellet, which is called stromal vascular fraction (SVF), was cultured at $37^{\circ} \mathrm{C}, 5 \% \mathrm{CO}_{2}$ to increase the number of cells or to facilitate cell proliferation. After the cells' culture reached $80-90 \%$ confluency, they were harvested enzymatically using Trypsin-EDTA $(0.25 \%)$ and cryopreserved in liquid nitrogen.

\section{ADSC Characterization}

ADSC characterization included specific cell surface marker analysis and differentiation potency evaluation. The specific cell surface marker refers to the protocol in the Human MSC Analysis Kit (BD Stemflow ${ }^{\mathrm{TM}}$ ). ADSC passage 1 that reached $>80 \%$ confluency were harvested enzymatically using Trypsin-EDTA (0.25\%) (Gibco). Cell concentration at $5 \times 10^{6}-10^{7}$ cells $/ \mathrm{mL}$ was resuspended in $1 \mathrm{ml}$ staining buffer. After resuspension, a $100 \mu \mathrm{L}$ cells solution in the staining buffer was taken and added into the $5 \mu \mathrm{L}$ hMSC positive cocktail (CD90FITC, 
125

126

127

128

129

130

131

132

133

134

135

136

137

138

139

140

141

142

143

144

145

146

147

148

149

150

151

152

153

CD105PerCP-Cy5.5, CD73 APC), and hMSC negative cocktail (CD34 PE, CD11b PE, CD19 PE, CD45 PE, HLA-DR PE) antibody or isotype and incubated in the dark for 30 minutes. Then, the sample was washed twice in the staining buffer and resuspended in 300-500 $\mu \mathrm{L}$ staining buffer. Finally, the sample was analyzed using a flowcytometer.

For the differentiation analysis, ADSC passage 2 that reached $>80 \%$ confluency was harvested enzymatically in Trypsin-EDTA (0.25\%) (Gibco). ADSC were cultured in 24 wellplate $\left(1 \times 10^{4} \mathrm{sel} /\right.$ well) in the growth medium DMEM Low Glucose (Gibco) supplemented with 10\% FBS (Gibco). After reaching 80\% confluency, the growth medium was replaced with a chondrogenic induction medium (MesenCult ${ }^{\mathrm{TM}}$ Chondrogenesis Differentiation Kit), osteogenic induction medium (MesenCult ${ }^{\mathrm{TM}}$ Osteogenesis Differentiation Kit), and adipogenic induction medium (MesenCult ${ }^{\mathrm{TM}}$ Adipogenic Differentiation Medium (Human)). After 7-14 days incubation (for adipogenesis) and/or longer than 14 days (for chondrogenesis and osteogenesis), the cells were observed using an inverted microscope. The cells were fixed in $4 \%$ formaldehyde in saline and stained, using Alcian Blue staining which is specific for glycosaminoglycan, one of the components in chondrocytes extracellular matrix; Alizarin Red staining which is specific for mineralized matrix expression as osteoblast marker; and Oil Red O staining for lipid vacuoles in adipocyte marker. The excess dye stain was washed in PBS. The cell observation was performed by inverted microscope.

\section{Biocompatibility Analysis of Silk Fibroin Scaffold}

Biocompatibility of the silk fibroin scaffold was analyzed using 3-(4,5-Dimethylthiazol-2-yl)2,5-diphenyltetrazolium bromidefor (MTT Assay). ADSC $\left(1 \times 10^{5}\right.$ cells $\left./ \mathrm{mL}\right)$ were grown on a sterile scaffold $(0.5 \mathrm{~cm} \times 0.5 \mathrm{~cm} \times 1 \mathrm{~mm})$ in 96 well-plate. The cells were maintained in growth medium (supplemented with DMEM) and incubated at $37^{\circ} \mathrm{C} ; 5 \% \mathrm{CO}_{2}$. The effect on ADSC at days $1,3,5,7$, and 14 after being cultured was evaluated using MTT assay. For the cytotoxicity assay, the growth medium was discarded, and then $10 \mu \mathrm{L}$ of MTT reagent $(5 \mathrm{mg} / \mathrm{mL})$ was added into $100 \mu \mathrm{L}$ growth medium. The cells were incubated in MTT solution for 4 hours at $37^{\circ} \mathrm{C}$ in the dark. After that, the MTT solution was removed, and $100 \mu \mathrm{L}$ dimethyl sulfoxide (DMSO) was added to dilute the formazan crystal that had formed. The absorbance of the solution was read at $570 \mathrm{~nm}$ wavelength using a microplate reader (Bio-Rad). The observation was repeated 3 times. 
154

155

156

157

158

159

160

161

162

163

164

165

166

167

168

169

170

171

172

173

174

175

176

177

178

179

180

181

\section{Scanning Electron Microscope (SEM) Analysis}

ADSC morphology was analyzed using a scanning electron microscope (SEM) (Hitachi SU 3500 , Center of Advanced Science ITB) after being seeded on the scaffold. ADSC ( $10^{6}$ cells $\left./ \mathrm{mL}\right)$ were grown on the sterile scaffold $(0.5 \mathrm{~cm} \times 0.5 \mathrm{~cm} \times 1 \mathrm{~mm})$ in 96 well-plate. The cells were maintained in the growth medium and incubated at $37^{\circ} \mathrm{C} ; 5 \% \mathrm{CO}_{2}$. SEM analysis was done on cells cultured for 1 and 21 days.Cells were fixed in $100 \mu \mathrm{L}$ of 2,5\% (v/v) glutaraldehyde in 0.1 $\mathrm{M}$ cacodylate buffer (Electron Microscopy Science), and incubated for 24 hours at $4^{\circ} \mathrm{C}$. The sample was dehydrated using an ascending alcohol series and dried by the freeze drying method for 3 hours. The dried sample was sputtered with gold coating and observed under SEM.

\section{Optimization of LAA and PRP concentration}

Cell proliferation in optimization LAA and PRP concentration was analyzed using MTT assay, and the cell differentiation was analyzed using Alcian Blue staining. ADSC (1x $10^{5}$ cells $/ \mathrm{mL}$ ) were seeded on 96 well-plate. The concentrations of LAA solution in the induction medium were $25 \mu \mathrm{g} / \mathrm{mL}, 50 \mu \mathrm{g} / \mathrm{mL}, 100 \mu \mathrm{g} / \mathrm{mL}$, and $200 \mu \mathrm{g} / \mathrm{L}$. The concentrations of PRP solution (platelet content approximately $1.086 \times 10^{6} / \mu \mathrm{L}$ ) in the induction medium with $1 \%$ heparin added were $5 \%, 10 \%$, and $20 \%$. The cell cultures were placed in an incubator at $37^{\circ} \mathrm{C}$; $5 \% \mathrm{CO}_{2}$ in the induction medium, and replaced every 2 days. Proliferation analysis was observed on days 1, 3, 5, 7, and 14. In addition, the differentiation potency was analyzed using extracellular matrix staining for sulfated-GAG as a chondrocytes marker. ADSC $\left(10^{4}\right.$ cells $\left./ \mathrm{mL}\right)$ were grown on 24 well-plate, and the cells were incubated at $37^{\circ} \mathrm{C} ; 5 \% \mathrm{CO}_{2}$, and the medium was replaced every 2 days. On days 14 and 21, the cells were prepared for Alcian Blue staining and observed using an inverted microscope to evaluate chondrogenic differentiation. Data were taken in triplicate for each group on every observational day. The intensity of blue colour as the staining result indicated that glycosaminoglycan extracellular matrix had formed. Blue colour intensity was quantified using the software Digimizer (MedCalc).

Analysis of Glycosaminoglycan (GAG) Content

ADSC $\left(10^{6}\right.$ cells $\left./ \mathrm{mL}\right)$ were grown on a scaffold in LAA induction medium and PRP induction medium. On days 7, 14, and 21, the cell culture was washed in PBS before being fixed using an 
182 acetone:methanol $(1: 1)$ solution at $4^{\circ} \mathrm{C}$ for 3 minutes. One percent Alcian Blue in $3 \%$ acetic acid

183

184

185

186

187

188

189

190

191

192

193

194

195

196

197

198

199

200

201

202

203

204

205

206

207

208

209

210 was added into the cell culture. The cells were incubated for 30 minutes and the overstaining dye was washed in 3\% acetic acid and deionized water. One percent of Sodium dodecyl sulfate (SDS) was added to the cell culture and homogenized using a shaker at $200 \mathrm{rpm}$ for 30 minutes. The absorbance was read using a microplate reader at $605 \mathrm{~nm}$ wavelength. The observation was repeated 3 times.

\section{RESULT}

\section{ADSC Characteristics}

Observation using a light microscope showed that cells had a spindle-like morphology, which is flattened. The cells had formed lamellipodium, indicating their complete adherence on the polystyrene flask in the standard culture condition. According to Lotfy et al.( 2014), ADSC morphology in their standard culture condition was fibroblast-like and fusiform (spindle-like shape). The population doubling time (PDT) of ADSC was 42.9 hours, while that of Griffin et al. (2017) was $39,88 \pm 4.4$ hours. This difference in PDT could be due to the cell passage and genetic variation of donors determined by PDT of ADSC.

Figure 01. Flow cytometry result of specific ADSC cell surface marker, positive markers; CD90 (A), CD73 (B), CD105 (C), and negative marker CD45, CD34, CD11b, CD19, HLA-DR (D); red peak represents the isotype peak, blue peak represents the sample peak, and red line represents the percentages of sample.

The cell surface markers that were used to confirm MSC were cluster of differentiation 90 (CD90), CD73, and CD105 as positive markers, and CD45, CD34, CD11b, CD19, HLA-DR, as negative markers. The singlet and sharp peaks in the graphs show that there was a single population of the cells. The positive and negative markers had the singlet and sharp peak. The ADSC expressed the positive markers CD90 (91.38\%), CD73 (96.25\%), and CD105 (61.33\%). However, the sample and isotype peak of the negative markers overlapped, decreasing the percentage $(0.38 \%)$ (Figure 01$)$. The MSC must express those three positive markers exceeding $90 \%$ of cell population, while the MSC must express negative markers until below $2 \%$ 
211 (Dominici et al. 2006). Our result showed that ADSC expressed CD90 (91.38\%), CD73

212 (96.25\%), and CD105 (61.33\%), and the negative markers were expressed only in a small 213 percentage $(0.38 \%)$ (Figure 01$)$.

214

215

216

217

218

219

220

221

222

223

224

225

226

227

228

229

230

231

232

233

234

235

Figure 02. Result of Alcian Blue (A), Alizarin Red (B), and Oil Red O (C) staining in ADSC culture induced with differentiation induction medium, and the non-staining group (D). Black arrows showthe positive result for each staining group.

The multipotency analysis showed that ADSC complied with one of the MSC criteria, which could be differentiated into three mesenchymal stem cell derivative cells: chondrocyte, osteocyte, and adipocyte (Figure 02).

\section{Optimization of Silk Fibroin Scaffold}

Figure 03. ADSC growth curve on scaffold in different silk fibroin concentrations To promote stronger cell adhesion and faster cell growth, often some modifications are made on scaffolds. To achieve the best support of ADSC growth, we optimized silk fibroin concentration and pore size. Figure 03 depicts that the percentage of cell viability increased gradually within 14 days in different silk fibroin concentrations, indicating that the cells seeded on all scaffolds proliferated actively. On day 14 , the scaffold made from $8 \% \mathrm{w} / \mathrm{v}, 10 \% \mathrm{w} / \mathrm{v}$, and $12 \% \mathrm{w} / \mathrm{v}$ had higher percentages of cell viability than the control group, and the $12 \% \mathrm{w} / \mathrm{v}$ silk fibroin scaffold had the highest score.

Figure 04. Growth curve of ADSC on scaffolds with different pore sizes Figure 04 shows that all scaffolds supported cell proliferation and maintained cell viability. Apparently, pore size could affect ADSC proliferation. The percentage of cell viability in scaffold with $500 \mu \mathrm{m}$ pore size was the highest; . thus, this scaffold appears to have been the optimal one for supporting ADSC proliferation.

\section{Biocompatibility Analysis of Silk Fibroin Scaffold}


236

237

238

239

240

241

242

243

244

245

246

247

248

249

250

251

252

253

254

255

256

257

258

259

260

261

262

263

264

265

266

Figure 05. SEM image representing morphology of scaffold made from $12 \% \mathrm{w} / \mathrm{v}$ silk fibroin with 500 $\mu \mathrm{m}$ pore size (Judawisastra\&Wibowo, 2017) A) Magnification 50X; B) Magnification 200X; (I---I) represents pore size; the head arrow represents interconnected pores.

SEM images were taken to characterize the structure of the silk fibroin scaffold. Based on the SEM analysis presented in Figure 05, the scaffold made from 12\%w/v silk fibroin formed 500 $\mu \mathrm{m}$ pores. The scaffold had an average pore size $536 \pm 97 \mu \mathrm{m}$ and an interconnected porous structure.

Figure 06. Morphology of ADSC on scaffold made from 12\%w/v silk fibroin, with 500 $\mu \mathrm{m}$ pore size. A) single cell on day 1; B) single cell on day 21 ; C) cell population on day 1; D) cell population on day 21. Red arrow shows cytoplasm extension, called filopodia. Yellow arrow and yellow dashed line show area covered by cells.

It is known that the surface roughness of a scaffold is an important factor in promoting cell attachment (Acharya et al. 2009). Figure 06A-B shows that ADSC cells formed a fillipodia structure which might be one of the factors that promoted fast attachment of ADSC cells in this study. The SEM image also shows the cell structure that attached to the scaffold on days 1 and 21 (Figure 06C-D). The images indicate that the scaffold could support ADSC proliferation, which is in line with the growth curve (Figure 07).

Figure 07. Growth curve of ADSC on scaffold made from $12 \% \mathrm{w} / v$ silk fibroin, with $500 \mu \mathrm{m}$ pore size

The growth curve of ADSC determined by the MTT assay on the optimized scaffold showed the desired increase of viable cells between days 1-21 (Figure 07). The curve shows a lag phase of cell growth from days 1 to 7 and the log phase after day 7 .

Figure 08. ADSC population observed on day 21 in A) monolayer formation and B) aggregation

SEM images of tissue formation on the scaffold were obtained on day 21 to examine the tissue structure as the cell had reached full density on the scaffolds surface. The SEM result showed the presence of two cell populations on the scaffolds. One formed a monolayer and the other showed aggregates. Based on the scaffolds optimization experiments above related to ADSC cell viability, growth, and proliferation, we found that $12 \% \mathrm{w} / \mathrm{v}$ silk fibroin with $500 \mu \mathrm{m}$ pore size was the best candidate to promote ADSC cell adhesion and tissue formation (Figure 08). 
267

268

269

270

271

272

273

274

275

276

277

278

279

280

281

282

283

284

285

286

287

288

289

290

291

292

293

294

295

\section{Optimization of LAA and PRP concentration}

Figure 09. Growth curve of ADSC in L-ascorbic acid (LAA) supplemented medium in various concentrations

To assess the best concentration of bioactive factors to induce cell proliferation in our experiment, we added LAA or PRP at various concentrations to growth medium and examined the cell proliferation by MTT assay independently. Figure 09 shows the growth curve of ADSC in the presence of LAA at various concentrations. The graphs depict that $25 \mu \mathrm{g} / \mathrm{mL}, 50 \mu \mathrm{g} / \mathrm{mL}$, $100 \mu \mathrm{g} / \mathrm{mL}$, and $200 \mu \mathrm{g} / \mathrm{mL}$ LAA increased the percentage of cell viability from day 1 to 21 of observation. Our data showed that the addition of LAA promoted faster cell proliferation than in cells not treated with LAA, and the best LAA concentration was $50 \mu \mathrm{g} / \mathrm{mL}$. However, there were no significant differences among various concentrations of LAA. This result indicates that LAA supported ADSC cell proliferation.

Figure 10. Graph of blue color intensity comparison from Alcian Blue staining in various LAA concentrations

The quantification using Digimizer software showed the blue color intensity in various LAA concentrations (Figure 10). The result shows that ADSC in LAA supplemented medium secretes more GAG than the cells grown in standard medium. However, the amount of GAG was not significantly different among groups ( $\mathrm{p}>0.05$ ), and blue color intensity in the $50 \mu \mathrm{g} / \mathrm{mL}$ treatment group tended to be higher compared to the other groups.

Figure 11. Growth curve of ADSC in various platelet rich plasma (PRP)

concentrations of medium

Figure 11 showed ADSC proliferation in various PRP concentrations in the induction medium. The cells grown in the induction medium supplemented with 5\%,10\%, and 20\% PRP showed an increasing percentage of cell viability from days 1 to 21 . The percentage of cell viability from various PRP concentrations were higher than that without PRP (supplemented with FBS). This result indicated that PRP supported ADSC cell proliferation. Among various PRP concentrations, cell viability in 10\% PRP was higher than the other concentration on every observational day. From this result, we concluded that 10\% PRP in the induction medium was the optimum concentration to promote cell proliferation. 
Figure 12. Graph of blue colour intensity comparison from Alcian Blue

298

299

300

301

302

303

304

305

306

307

308

309

310

311

312

313

314

315

316

317

318

319

320

321

322

323

324

Similar to the LAA experiment, GAG production in cells treated with PRP was assessed with Alcian Blue staining. The Alcian Blue intensity of cells treated with various PRP concentrations was quantified (Figure 12). As shown in Figure 12, 10\% and 20\% PRP concentration caused higher production of GAG than the control group (supplemented with FBS); the blue color intensity in the 5\% PRP concentration and the FBS group did not show any siginificant difference $(\mathrm{p}>0.05)$. Furthermore, the blue color intensity in 20\% PRP concentration was lower than the blue color intensity in 10\% PRP concentration. Based on these results, we conclude that $10 \%$ PRP concentration had the best potency in chondrogenic differentiation.

\section{Evaluation of ADSC Differentiation on Scaffold in LAA Induction Medium and PRP} Induction Medium

Figure 13. Graph of glycosaminoglycan (GAG) content in ADSC cultured on scaffold in $50 \mu \mathrm{g} / \mathrm{mL}$ LAA and $10 \%$ PRP supplemented medium

Further, we examined the best concentration of LAA and the PRP effect on ADSC differentiation grown on optimized scaffold. To assess cell differentiation, production of GAG on the grown culture was analyzed based on Alcian Blue absorbance at $650 \mathrm{~nm}$ (Figure 13). Both the absorbance value of Alcian Blue stained cells in $50 \mu \mathrm{g} / \mathrm{mL}$ LAA and $10 \%$ PRP increased gradually from day 7 to 21 . The absorbance value in LAA induction medium or PRP induction medium were higher than that of the control group (supplemented with FBS). Based on the graph, $50 \mu \mathrm{g} / \mathrm{mL}$ of LAA or $10 \%$ PRP induction medium could induce chondrogenic GAG production of ADSC grown on scaffold.

\section{DISCUSSION}

Cartilage tissue damage can be overcome by implanting cartilage tissue in the damaged area, but sources of cartilage tissue are limited. In this research,we utilized MSC from adipose tissue (ADSC) to be differentiated to chondrocytes. Based on multipotency assessment and morphology observation, we confirmed that the ADSC used in this study complied with criteria described for healthy and potent ADSC. Our ADSC showed an ability to differentiate into 
325 chondrocytes, adipocytes, and osteocytes. Furthermore, it also complied with the standards of the

326 International Society for Cellular Therapy(ISCT) (Dominici et al. 2006).

327 Following the international standard for MSC surface markers declared by ISCT, further 328 assessment of ADSC used in this study showed it complied with those criteria, except lower 329 expression of endoglin marker (CD105) than the standard. However, CD105 expression of 330 ADSC has been described as inconsistent and depends on many factors such as cell source, cell 331 passage, isolation method, incubation duration, and growth phase of cells (Baer and Geiger 332 2012). Early passage cells used in our experiment might be the reason for lower expression of 333 CD105 (Crisan et al. 2008). However, based on other markers and morphology analysis, we 334 concluded our grown culture matches ADSC. CD105 is not the main marker to characterize MSC from adipose tissue, and it is recommended only as an alternative or additional marker (Bourin et al. 2013).

337 The multipotency evaluation of ADSC showed that the cells could be differentiated into chondrocytes, osteocytes, and adipocytes. The same result was obtained by Hamid et al. (2012) showing that ADSC has the differentiation capacity to become chondrocyte, osteocyte, and adipocyte when cultured in a standard induction medium. Therefore, ADSC used in this research complied with MSC criteria.

342 Based on the optimization of the scaffold, the optimum cell proliferation was obtained on the 343 $12 \%$ silk fibroin scaffold. Based on previous study, the mechanical strength of a scaffold is an important factor in articular cartilage tissue engineering because cartilage has a role as facilitator in body mass transmission in movement (Fox, Bedi \& Rodeo 2009). We speculatethat higher silk fibroin concentration increased the mechanical strength of scaffold. The optimum cell proliferation was also facilitated by the scaffold pore size $500 \mu \mathrm{m}$, which is the best pore size obtained in a previous experiment (Judawisastra \& Wibowo 2017). The result of our research was in line with Murphy et al., (2010) concluding that a scaffold with a bigger pore size facilitates the cells to proliferate faster than the cells seeded on a scaffold with small pore size. Bigger pore size may also facilitate faster cell migration. The pore structure also affects the roughness of the scaffold's surface, which is one of the important factors for cell attachment (Acharya et al. 2009). 
354 This research showed that within 21 days there were only 2 phases of growth curve pattern, 355 compared to in the standard culture condition which has 3 phases in shorter observational days. 356 This pattern was different from the ADSC growth pattern in the standard culture condition. 357 According to Christodoulou et al.( 2013), ADSC was in lag phase on days 1-3 and entered log 358 phase in days 3-8; and after day 8, ADSC started entering the stationary phase. The delayed 359 growth of ADSC on the scaffold could be due to the influence of the scaffold used in this

360

361

362

363

364

365

366

367

368

369

370

371

372

373

374

375

376

377

378

379

380

381

382

383

384 research, including the pore size. Therefore, the role of a scaffold in facilitating ADSC growth needs further investigation. Moreover, on day 21, two types of cell population were found on the scaffold: monolayer and aggregates; however, the existence of those cellpopulation types needs further investigation. According to Zhang et al. (2014), aggregation formation is very important in the initial stage of chondrogenic differentiation because it can facilitate extracellular matrix condensation.

Here, we confirmed that chondrogenesis can be induced by LAA in standard growth medium. Potdar and D'Souza (2010) also showed that an LAA addition in $250 \mu \mathrm{M}$ concentration into subcutaneous adipose tissue (SCAT) hMSC culture can increase the proliferation rate. The difference in LAA concentration that can increase cell proliferation rate could be due to the difference of cell source donor. Choi (2008) also showed that the role of LAA in MSC proliferation was dose-dependent. Moreover, chondrogenesis evaluation of cells treated with LAA has shown that $50 \mu \mathrm{g} / \mathrm{mL}(170 \mu \mathrm{M})$ of LAA could induce optimum chondrogenic differentiation. L-ascorbic acid was well known as inducer in chondrogenesis (Choi et al.,2008; (Kao et al., 1990), however, the mechanism has not been studied. Based on analysis of proliferation and chondrogenic differentiation potency, the cells in $50 \mu \mathrm{g} / \mathrm{mL}$ LAA showed the best proliferation rate and differentiation potency. Therefore, $50 \mu \mathrm{g} / \mathrm{mL}$ LAA concentration was chosen as the optimum concentration and used for the next investigation in this research. The LAA concentration in $50 \mu \mathrm{g} / \mathrm{mL}$ (approximately $170 \mu \mathrm{M}$ ) is also a general concentration of LAA used in standard chondrogenic induction medium.

In this research, PRP could also induce chondrogenesis because it contains many growth factors that can induce chondrogenesis in ADSC. In agreement with previous study, our study showed that PRP increases the proliferation rate of ADSC; specifically 10\% PRP induces the accumulation of chondrogenic GAG (Liao et al. 2015). As well as LAA, ADSC response to PRP was dose dependent with an optimum concentration of $10 \%$ to stimulate ADSC proliferation and 
385

386

387

388

389

390

391

392

393

394

395

396

397

398

399

400

401

402 403

differentiation Mardani et al. (2013). Spreafico et al. (2009) showed that PRP addition in culture medium was proved to increase the proteoglycan production, although the mechanism is still unknown. The result of our research was supported by Kim et al. (2012) who observed ADSC differentiation on silk fibroin porous scaffold and showed that ADSC could grow and produce chondrogenic GAG. In comparison to Kim et al. (2012), we also evaluated the PRP addition and found that chondrogenic differentiation showed the best when the cells were induced with PRP. Here, we have shown that the engineered silk fibroin scaffold with certain concentrations of LAA and PRP can be applied to maintain the survival of ADSC and stimulate chondrogenesis, thereby providing a new and optimized method for cartilage tissue engineering.

\section{CONCLUSION}

In conclusion, $50 \mu \mathrm{g} / \mathrm{mL}$ of LAA or $10 \%$ PRP induction medium can induce optimum chondrogenic differentiation and growth of ADSC on $12 \% \mathrm{w} / \mathrm{v}$ silk fibroin scaffold which had $500 \mu \mathrm{m}$ pore size. The combination of scaffold and induction medium could faciltate the proliferation and differentiation of ADSC, leading to chondrocytes In the future, the result of this research could be developed for cartilage tissue engineering.

\section{ACKNOWLEDGEMENTS}

This research was facilitated by Klinik Yayasan Hayandra Peduli and HayandraLab. We thank Regina Giovanni for preparing the manuscipt.

\section{REFERENCES}

Acharya, C, Ghosh, SK \& Kundu, SC 2008, 'Silk fibroin film from non-mulberry tropical tasar silkworms: A novel substrate for in vitro fibroblast culture', Elsevier, vol 5, pp. 429437.

Akeda, K, An, HS, Okuma, M, Attawia, M, Miyamoto, K \& Thonar, EJ 2006, 'Platelet-rich plasma stimulates porcine articular chondrocyte proliferation and matrix biosynthesis', Osteoarthritis Cartilage, vol 14, pp. 1272-1280. 
Bacakova, L, Filova, E, Rypacek, F, Svorcik, V \& Stary, V 2004, 'Cell Adhesion on Artificial Materials for Tissue Engineering', Physiological Research, vol 53, no. 1, pp. s34-s45.

Baugé, C \& Boumédiene, K 2015, 'Use of Adult Stem Cells for Cartilage Tissue Engineering: Current Status and Future Developments', Stem Cells International, pp. 1-14.

Berghoff, WJ, Pietrzak, WS \& Rhodes, RD 2006, '2006', Platelet-rich plasma application during closure following total knee arthroplasty, vol 29, pp. 590-598.

Bourin, P, Bunnell, BA, Casteilla, L, Dominici, M, Katz, AJ, March, KL, Redl, H, Rubin, JP, Yoshimura, K \& Gimble, JM 2013, 'Stromal cells from the adipose tissue-derived stromal vascular fraction and culture expanded adipose tissue-derived stromal $/$ stem cells: a joint statement of the International Federation for Adipose Therapeutics (IFATS) and ISCT', Cytotherapy, vol 15, no. 6, pp. 641-648.

Brochhausen, C, Lehmann, M, Halstenberg, S, Meurer, A, Klaus, G \& Kirkpatrick, CJ 2009, 'Signalling molecules and growth factors for tissue engineering of cartilage - what can we learn from the growth plate?', J. Tissue Eng. Regen. Med., vol 3, pp. 416-429.

Bruzauskaite, I, Bironaite, D, Bagdonas, E \& Bernotiene, E 2016, 'Scaffold and Cells for Tissue Regeneration: Different Scaffold Pore Sizes-Different Cell Effect', Cytotechnology, vol 68, pp. 355-369.

Capito, RM \& Spector, M 2003, 'Scaffold-based Articular Cartilage Repair', IEEE Eng. Med. Biol. Mag., vol 22, pp. 42-50.

Choi, K-M, Seo, Y-K, Yoon, H-H, Song, K-Y, Kwon, SY, Lee, HS \& Park, JK 2008, 'Effect of Ascorbic Acid on Bone Marrow Derived Mesenchymal Stem Cell Proliferation and Differentiation', Journal of Bioscience and Bioengineering, vol 105, no. 6, pp. 586594.

Christodoulou, I, Kolisis, FN, Papaevangeliou, D \& Zoumpourlis, V 2013, 'Comparative Evaluation of Human Mesenchymal Stem Cells of Fetal (Wharton's Jelly) and Adult (Adipose Tissue) Origin during Prolonged In Vitro Expansion: Considerations for Cytotherapy', Stem Cells International.

Crisan, M, Yap, S, Casteilla, L, Chen, C, Corselli, M, Park, T, G, A, Sun, B, Zheng, B, Zhang, L, Norotte, C, Teng, PN, Traas, J, Schugar, R, Deasy, BM, Badylak, S, J., BH, Giacobino, JP, Lazzari, L, Huard, J, Peault B. 2008, 'A perivascular origin for mesenchymal stem cells in multiple human organs', Cell Stem Cell, vol 3, no. 3, pp. 301-313.

Doagă, IO, Savopol, T, Neagu, M, Neagu, A \& Kovács, E 2008, 'The Kinetics of Cell Adhesion to Solid Scaffolds: An Experimental and Theoretical Approach', J. Biol. Phys., vol 34, no. 5, pp. 495-509.

Dominici, M, Blanc, KL, Mueller, I, Slaper-Cortenbach, I, Marini, FC, Krause, DS, Deans, RJ, Keating, A, Prockop, DJ \& Horwitz, EM 2006, 'Minimal Criteria for Defining Multipotent Mesenchymal Stromal Cells. The InternationalSociety for Cellular Therapy Position Statement', Cytotherapy, vol 8, no. 4, pp. 315-317. 
Drengk, A, Zapf, A, Stürmer, EK, Stürmer, KM \& Frosch, K-H 2009, 'Influence of Platelet-Rich Plasma on Chondrogenic Differentiation and Proliferation of Chondrocytes and Mesenchymal Stem Cells', Cells Tissues Organs, vol 189, pp. 317-326.

Gessin, JC, Darr, D, Kaufman, R \& Murad, S 1988, 'Ascorbic Acid Specifically Increases Type I and Type III Procollagen Messanger RNA Level in Human Skin Fibroblast', J. Invest. Dermatol., vol 90, pp. 420-424.

Goessler, UR, Bieback, K, Bugert, P, Naim, R, Schafer, C, Sadick, H, Hormann, K \& Riedel, F 2005, 'Human chondrocytes differentially express matrix modulators during in vitro expansion for tissue engineering', Int. J. Mol. Med., vol 16, pp. 509-515.

Fox, A. J. S., Bedi, A., \& Rodeo, S. A., 2009, 'The Basic Science of Articular Cartilage : Structure, Composition, and Function', Orthopaedics Vol. 1, No. 6, pp. 461-468. DOI: $10.1177 / 1941738109350438$

Hamid, AA, Idrus, RBH, Saim, AB, Sathappan, S \& Chua, K-H 2012, 'Characterization of human adipose-derived stem cells and expression of chondrogenic genes during induction of cartilage differentiation', Clinics (Sao Paulo), vol 67, no. 2, pp. 99-106.

Hass, R, Kasper, C, Böhm, S \& Jacobs, R 2011, 'Different populations and sources of human mesenchymal stem cells (MSC): A comparison of adult and neonatal tissue-derived MSC', Cell Communication and Signaling, vol 9, no. 12, pp. 1-14.

Hunziker, EB 2002, ' Articular cartilage repair: basic science and clinical progress. A review of the current status and prospects', Osteoarthr. Cartil., vol 10, pp. 432-463.

Ikada, Y 2006, 'Challenges in tissue engineering', J. R. Soc. Interface, vol 3, no. 10, pp. 589-601.

Javidan, Y \& Schilling, TF 2004, 'The Zebrafish: Cellular and Developmental Biology', in SCFANE LaPointe (ed.), Methods in Cell Biology, Elsevier, USA.

Johnstone, B, Alini, M, Cucchiarini, M, Dodge, GR, Eglin, D, Guilak, F, Madry, H, Mata, A, Mauck, RL, Semino, CE \& Stoddart, MJ 2013, 'Tissue Engineering for Articular Cartilage Repair - The State of The Art', European Cells and Materials, vol 25, pp. 248-267.

Judawisastra, H \& Wibowo, UA 2017, 'Development of Biodegradable Silk Fibroin Scaffold for Tissue Engineering Applications', Research Finding, Institut Teknologi Bandung, The Asahi Glass Foundation, Bandung (in press).

Kao, J, Huey, G, Kao, R \& Stern, R 1990, 'Ascorbic Acid Stimulates Production of Glycosaminoglycan in Cultured Fibroblast', Exp. Mol. Pathol., vol 53, pp. 1-0.

Kim, HJ, Park, S-H, Durham, J, Gimble, JM, Kaplan, DL \& Dragoo, JL 2012, 'In vitro chondrogenic differentiation of human adipose-derived stem cells with silk scaffolds', J. Tissue Eng., vol 3, no. 1.

Kishi, K, Imanishi, N \& Ohara, H 2010, 'Distribution of adipose derived stem cells in adipose tissues from human cadavers', Journal of Plastic, Reconstructive and Aesthetic Surgery, vol 63, pp. 1717-1722.

Kock, L, Donkelaar, CCV \& Ito, K 2012, 'Tissue engineering of functional articular cartilage: the current status', Cell Tissue Res., vol 347, pp. 613-627. 
Li H1, ZL, Marra, KG, Donnenberg, VS, Donnenberg, AD \& Rubin, JP 2011, 'Adipogenic potential of adipose stem cell subpopulations', Plast. Reconstr. Surg., vol 128, no. 3, pp. 663-672.

Lian, X-J, Wang, S \& Zhu, H-S 2010, 'Surface properties and cytocompatibillity of silk fibroin films cast from aqueous solutions in different concentrations', Front. Mater. Sci. China, vol 4, no. 1, pp. 57-63.

Liao, HT, James, IB, Marra, KG \& Rubin, JP 2015, 'The Effects of Platelet-Rich Plasma on Cell Proliferation and Adipogenic Potential of Adipose-Derived Stem Cells', Tissue Eng. Part A., vol 21, no. 21-22, pp. 2714-2722.

Lotfy, A, Salama, M, Zahran, F, Jones, E, Badawy, A \& Sobh, M 2014, 'Characterization of Mesenchymal Stem Cells Derived from Rat Bone Marrow and Adipose Tissue: A Comparative Study', IJSC, vol 7, no. 2, pp. 135-142.

Mardani, M, Kabiri, A, Esfandiari, E, Esmaeili, A, Pourazar, A, Ansar, M \& Hashemibeni, B 2013, 'The Effect of Platelet Rich Plasma on Chondrogenic Differentiation of HUman Adipose Derived Stem Cells in Transwell Culture', Iranian Journal of Basic Medical Science, vol 16, no. 11.

Mason, JM, Breitbart, AS, Barcia, M, Porti, D, Pergolizzi, RG \& Grande, DA 2000, 'Cartilage and bone regeneration using gene-enhanced tissue engineering', Clin. Orthop. Relat. Res., vol 379, pp. 171-178.

Murphy, CM, Haugh, MG \& O'Brien, FJ 2010, 'The Effect of Mean Pore Size on Cell Attachment, Proliferation and Migration in Collagen-Glycosaminoglycan Scaffold for Bone Tissue Engineering', Biomaterials, vol 31, pp. 461-466.

Pawitan, JA, Suryani, D, Wulandari, D, Damayanti, L, Liem, IK \& Purwoko, RY 2014, 'Prolonged Culture in FBS and FBS-SubtituteContaining Media: Spontaneous Chondrogenic Differentiationof Adipose Tissue Derived Mesenchymal Stem Cells', Pharm. Tech. Resp., vol 6, no. 1, pp. 224-235.

Potdar, PD \& D'Souz, SB 2010, 'Ascorbic acid induces in vitro proliferation of human subcutaneous adipose tissue derived mesenchymal stem cells with upregulation of embryonic stem cell pluripotency markers Oct4 and SOX 2', Human Cell, vol 23, pp. 152-155.

Qasim, BJ, Ali, HH \& Hussein, AG 2011, 'Immunohistochemical Expression of Estrogen and Progesterone Receptors in Human Colorectal Adenoma and Carcinoma Using Specifed Automated Cellular Image Analysis System: A Clinicopathological Study', Oman Medical Journal, vol 26, no. 5, pp. 307-314.

Ramezanifard, R, Kabiri, M \& Ahvaz, HH 2017, 'Effects of platelet rich plasma and chondrocyte co-culture on MSC chondrogenesis, hypertrophy and pathological responses', EXCLI J., vol 16, pp. 1031-1045.

Servoli, E, Maniglio, D, Motta, A, Predazzer, R \& Migliares, C 2005, 'Surface Properties of Silk Fibroin Films and Their Interaction with Fibroblast', Macromol. Biosci., vol 5, pp. $1175-1183$. 
Spreafico, A, Chellini, F, Frediani, B, Bernardini, G, Niccolini, S, Serchi, T, Collodel, G \& Alessandro Paffetti 2009, 'Biochemical Investigation of the Effects of Human Platelet Releasates on Human Articular Chondrocytes', Journal of Cellular Biochemistry, vol 108, pp. 1153-1165.

Stoop, R 2008, 'Smart Biomaterials for Tissue Engineering of Cartilage', Injury, vol 39, no. 1, pp. 77-87.

Temu, TM, Wu, K-Y, Gruppuso, PA \& Phornphutkul, C 2010, 'The mechanism of ascorbic acidinduced differentiation of ATDC5 chondrogenic cells', Am. J. Physiol. Endocrinol. Metab., vol 299, pp. E325-E344.

Wang, Y, Blasioli, DJ, Kim, H-J, Kim, HS \& Kaplan, DL 2006, 'Cartilage Tissue Engineering with

Yamamoto, I, Muto, N, Murakami, K \& Akiyama, J 1992, 'Collagen synthesis in human skin fibroblasts is stimulated by a stable form of ascorbate, 2-O-alpha-D-glucopyranosyl L-ascorbic acid', J. Nutr., vol 122, pp. 871-877.

Zhang, J, Wu, Y, Thote, T, Lee, EH, Ge, Z \& Yang, Z 2014, 'The influence of scaffold microstructure on chondrogenic differentiation of mesenchymal stem cells', Biomed. Mater., vol 9.

Zuk, PA, Zhu, M, Ashjian, P, D.A., DU, Huang, JI, Mizuno, H, Alfonso, ZC, Fraser, JK, Benhaim, P \& Hedrick, MH 2002, 'Human adipose tissue is a source of multipotent stem cells', Mol. Biol. Cell., vol 13, pp. 4279-4295 
Figure 1

Flow cytometry result of specific ADSC cell surface markers

Cell expressed positive markers (A) CD90, (B) CD73, (C) CD 105, and (D) negative marker CD45, CD34, CD11b, CD19, HLA-DR
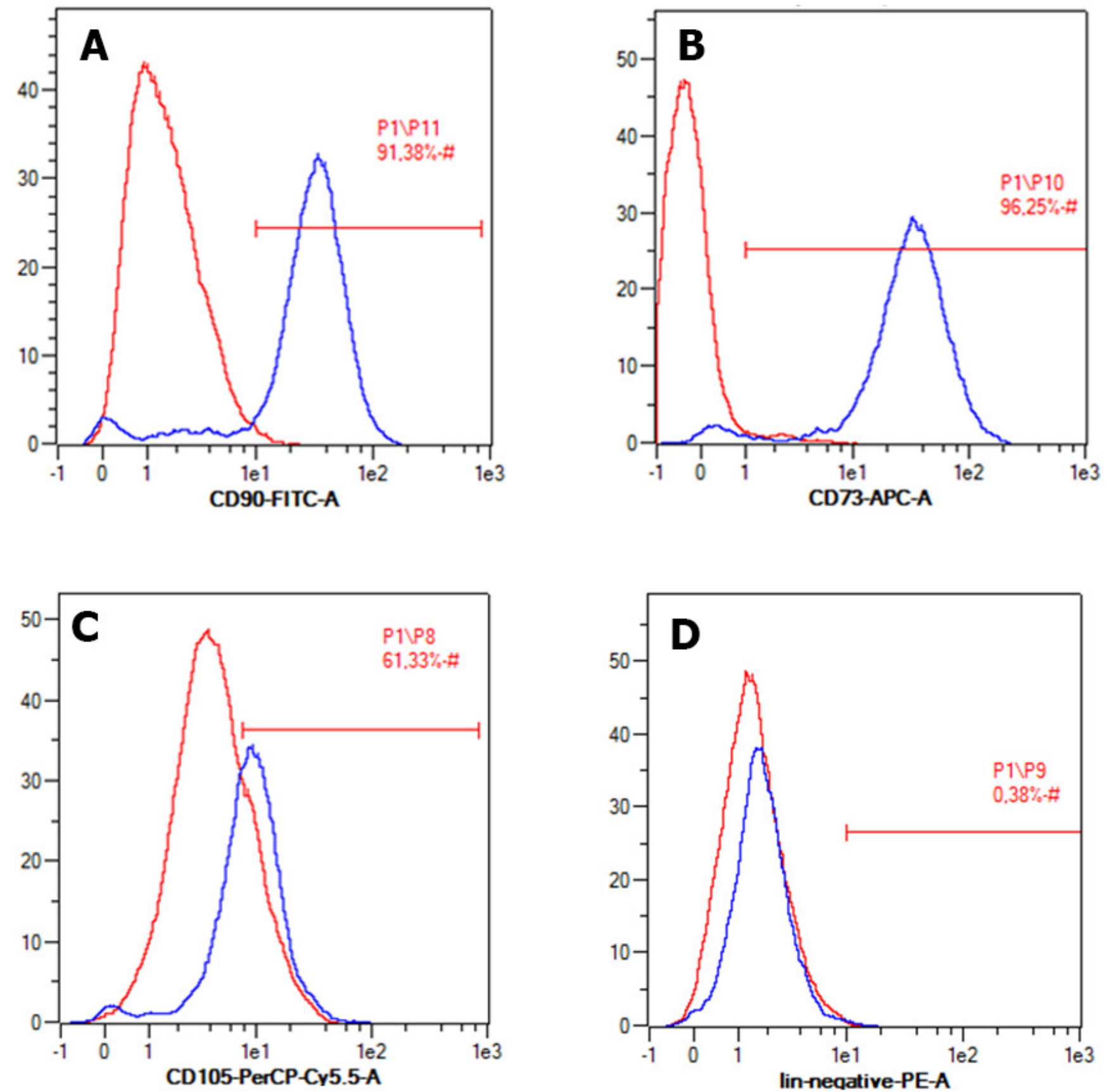


\section{Figure 2}

Multipotency evaluation of ADSC

(A) Alcian Blue Staining, (B) Alizarin Red and (C) Oil Red O in ADSC cultured which was induced with differentiation induction medium, and (D) non-staining group. Black arrow showed positive result from each staining group.
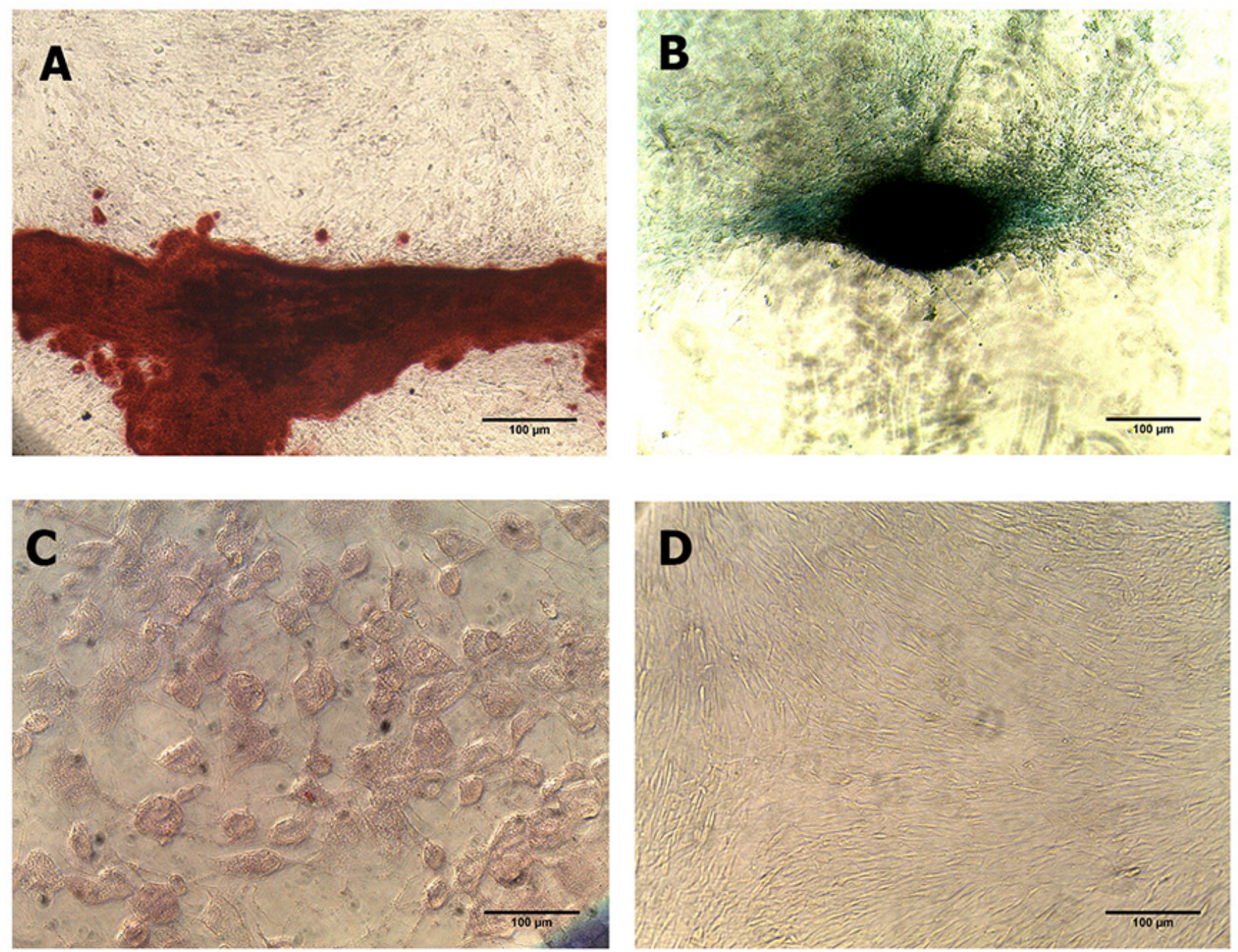
Figure 3

Growth Curve of ADSC on Scaffold in different silk fibroin concentration

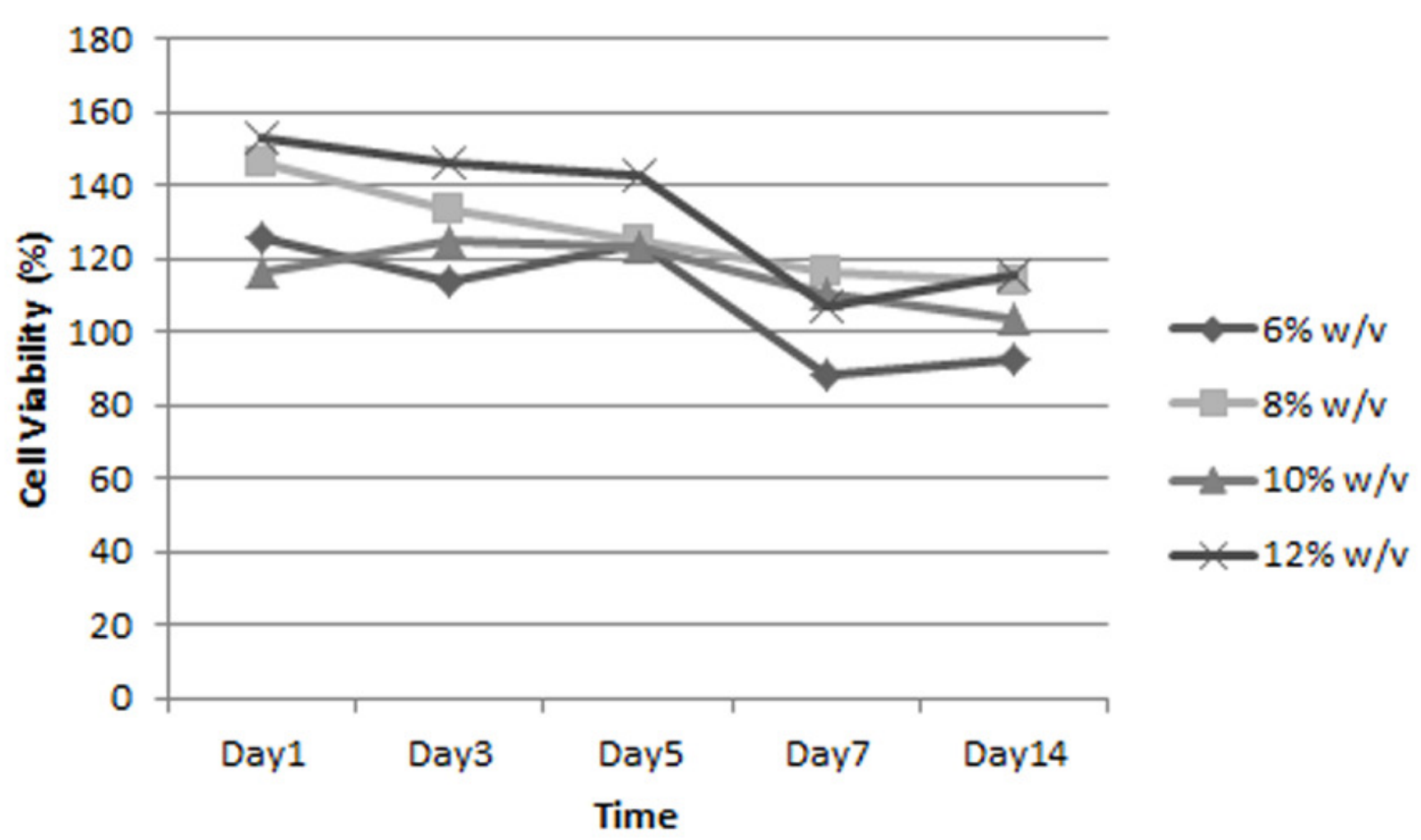


Figure 4

Growth curve of ADSC on Scaffolds that have different pore size

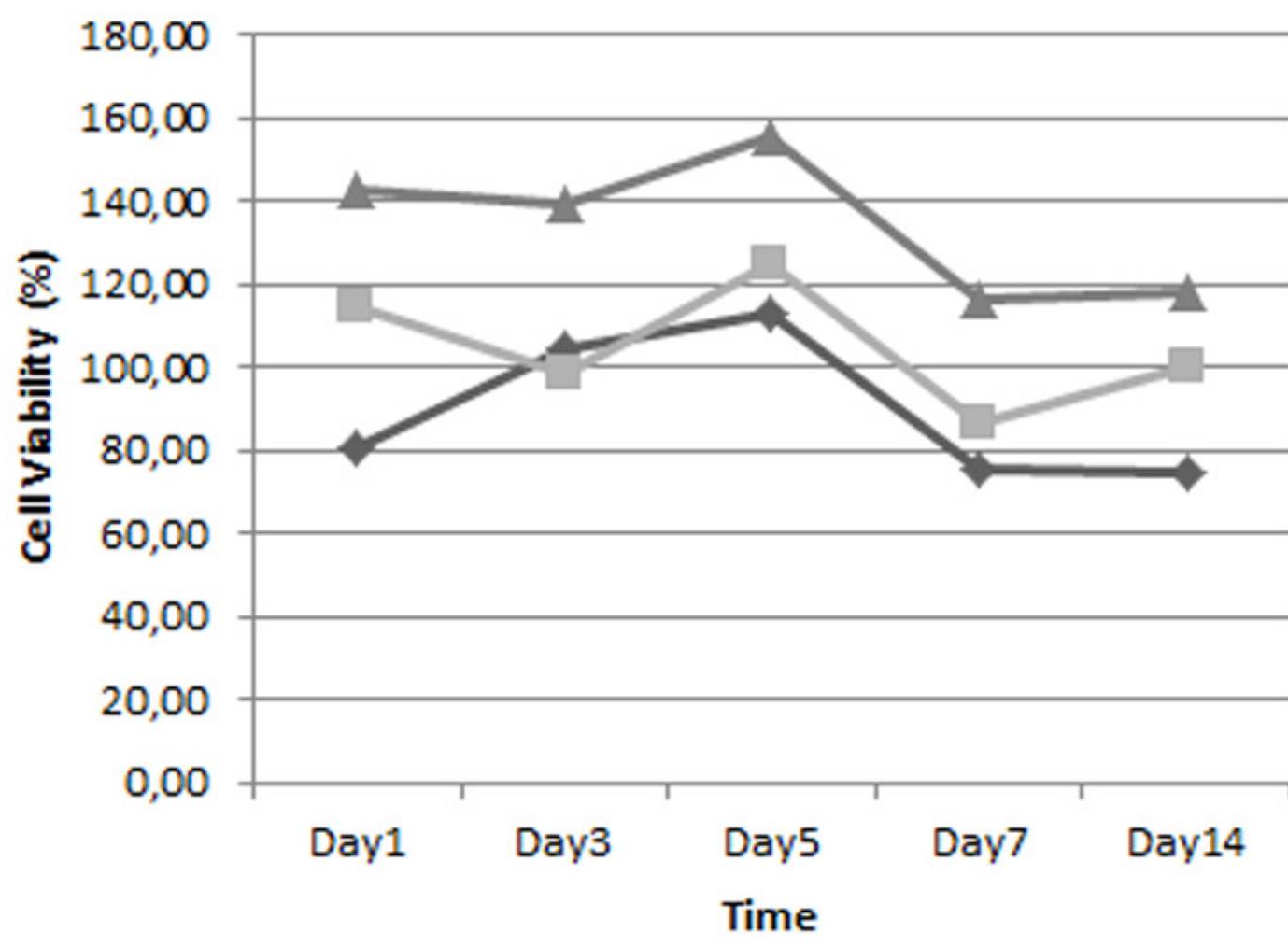

$\sim 100 u m$

$-300 u m$

$-500 u m$ 


\section{Figure 5}

SEM image represented morphology of scaffold

Scaffold was made from $12 \%$ w/v silk fibroin and had $500 \mu \mathrm{m}$ pore size ( Judawisastra \& Wibowo, 2017 ) (I-----I) represents pore size

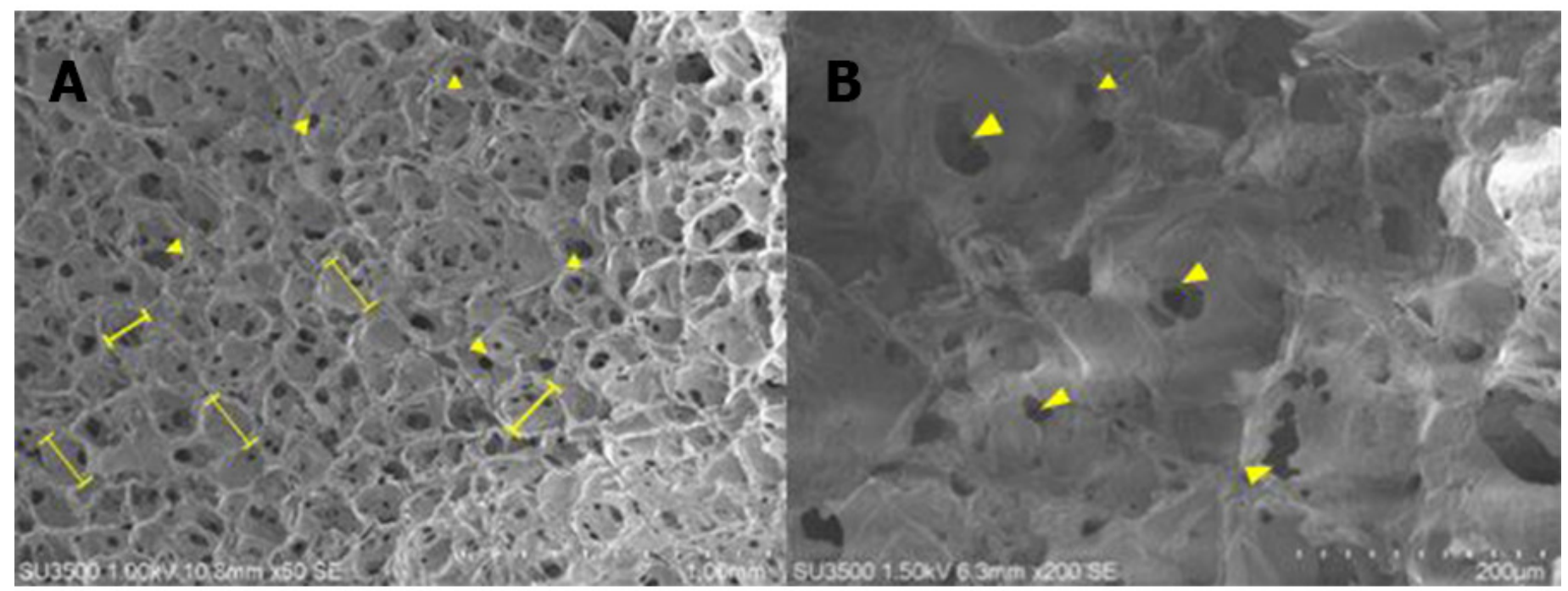




\section{Figure 6}

Morphology of ADSC on scaffold made from $12 \% \mathrm{w} / \mathrm{v}$ silk fibroin and had $500 \mu \mathrm{m}$ pore size.

Single cell was on (A) day 1 and (B) day 21. Cell population was on (C) day 1 and (D) day 21. Red arrow shows cytoplasm extension, called filopodia. White arrow and the area marked with yellow stripe line show the area covered by cells. 


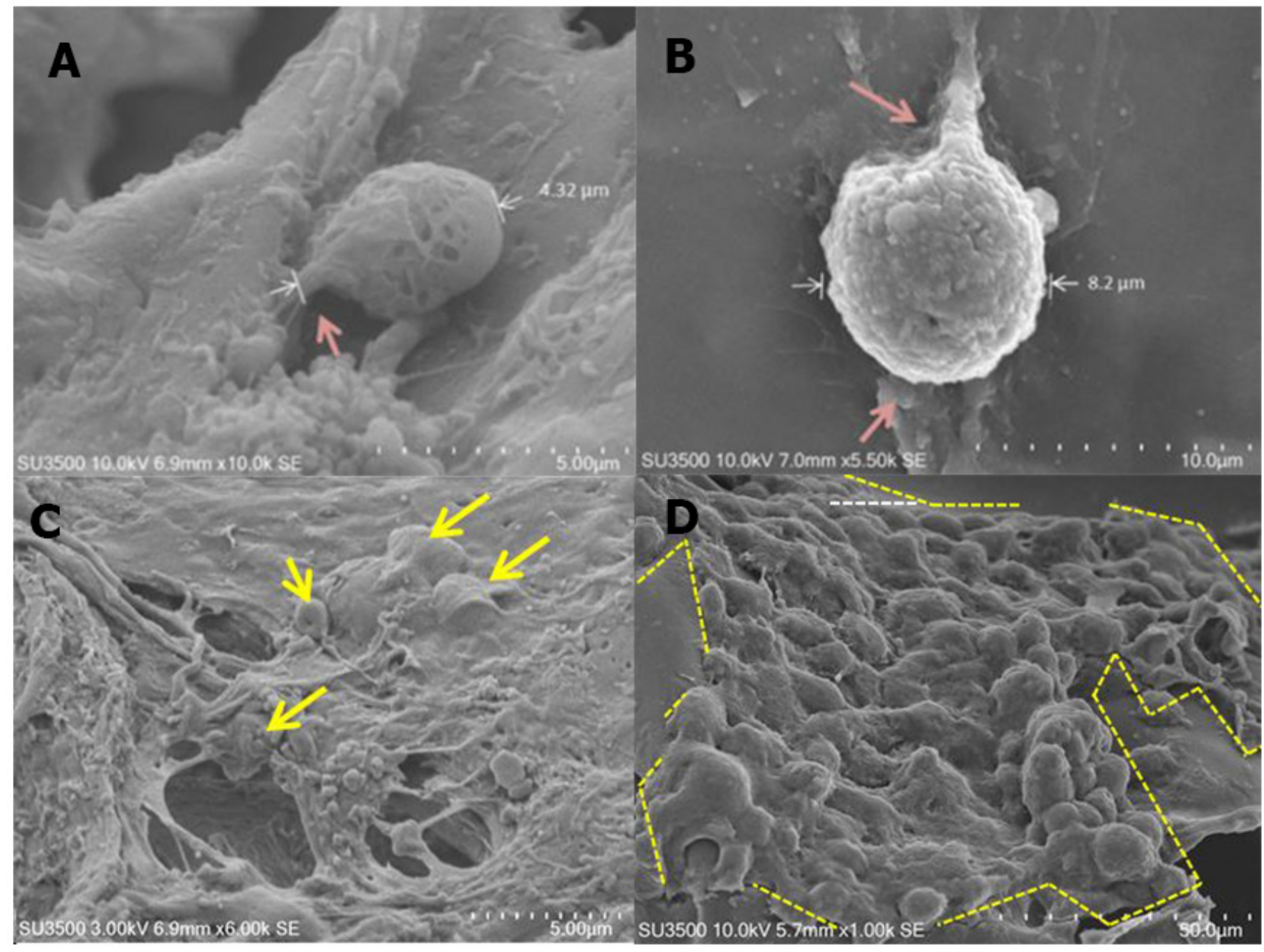


Figure 7

Growth curve of ADSC on Scaffold made from $12 \%$ w/v Silk Fibroin and had $500 \mu m$ pore size

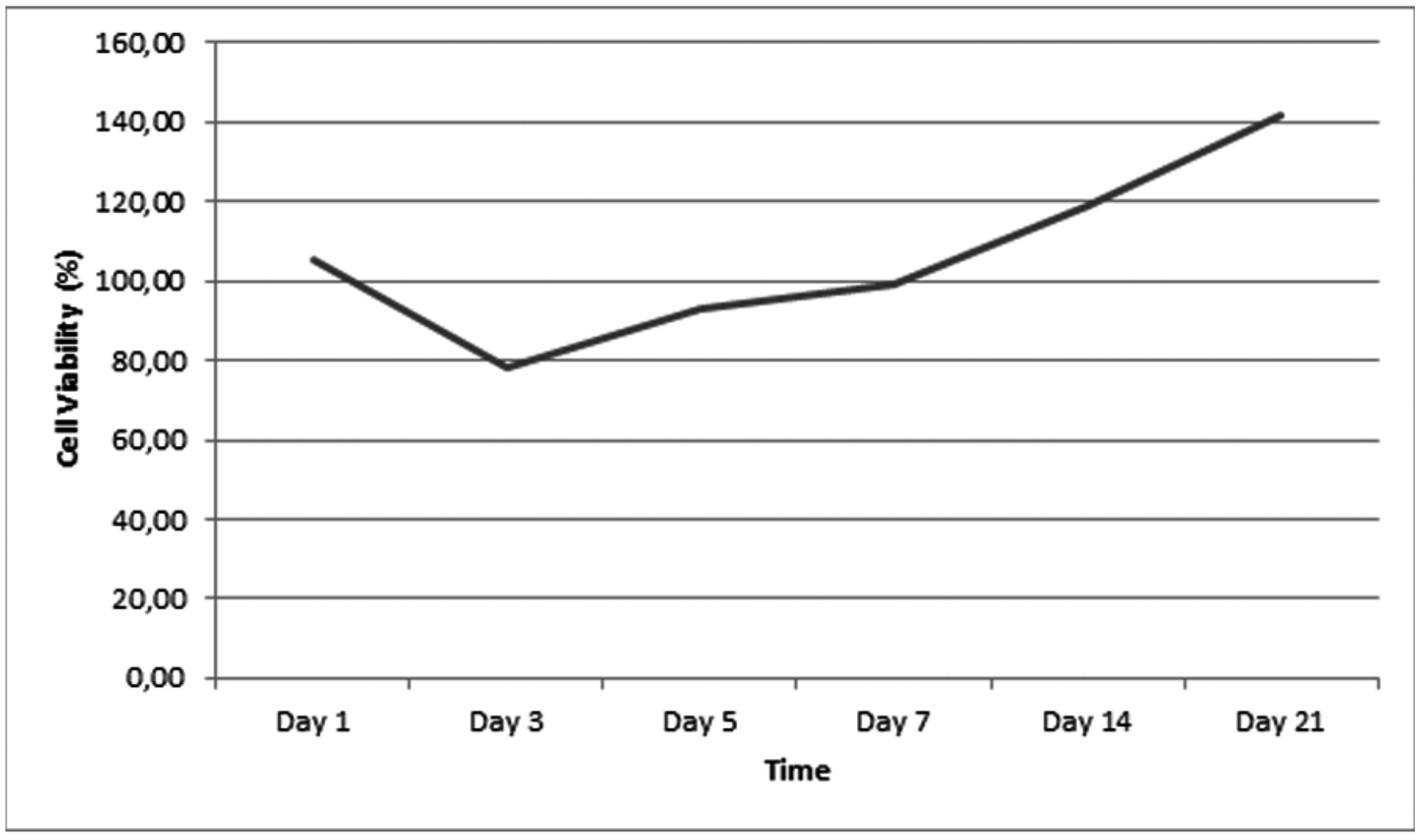




\section{Figure 8}

ADSC population observed on day 21

There are two types of cell population in (A) monolayer formation and (B) aggregation.

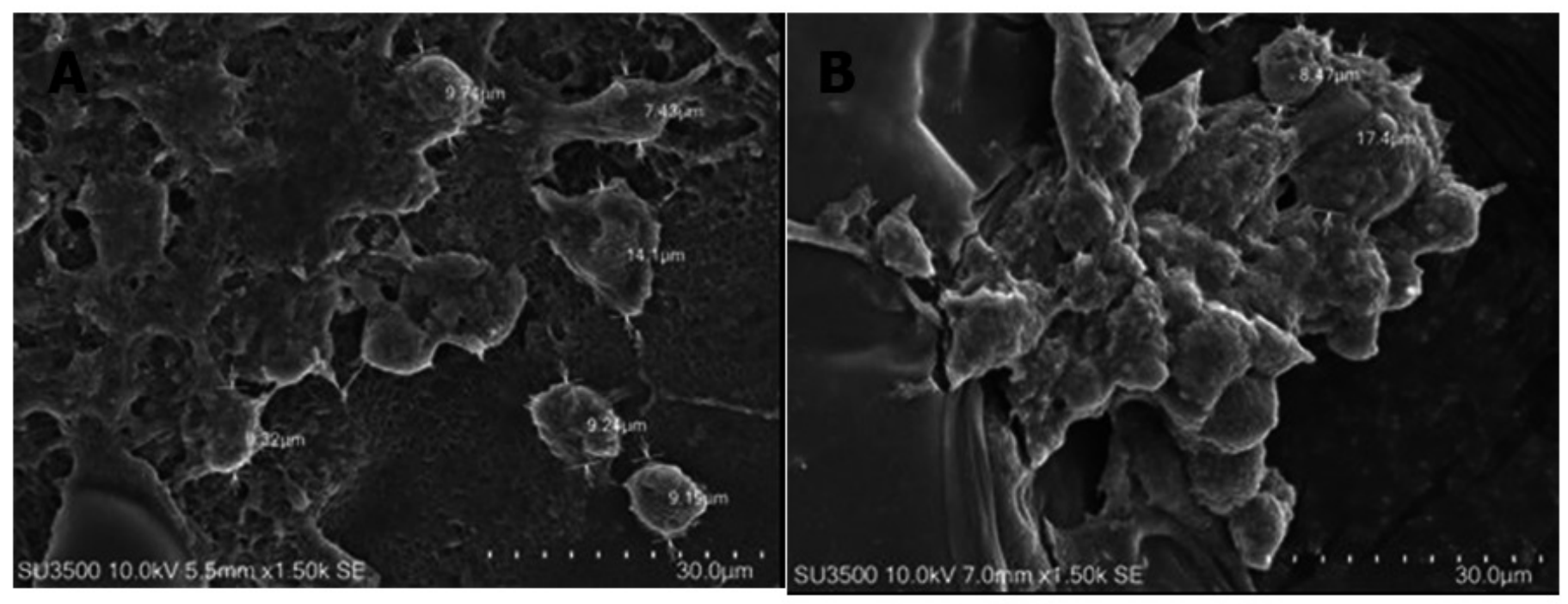


Figure 9

Growth curve of ADSC in L-Ascorbic Acid (LAA) supplemented medium in various concentration.

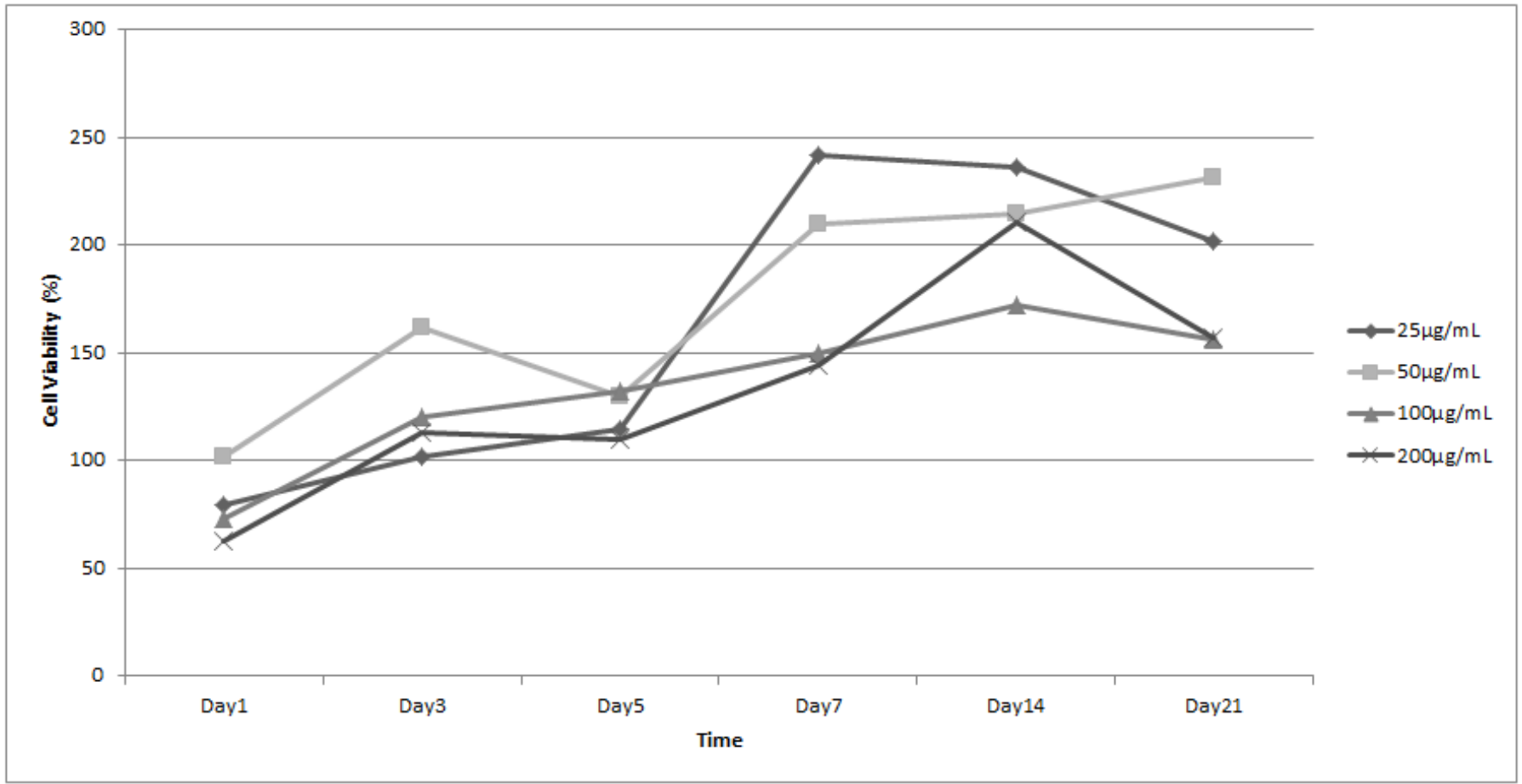


Figure 10

Graph of Blue Colour Intensity Comparison from Alcian Blue Staining in Various LAA Concentration

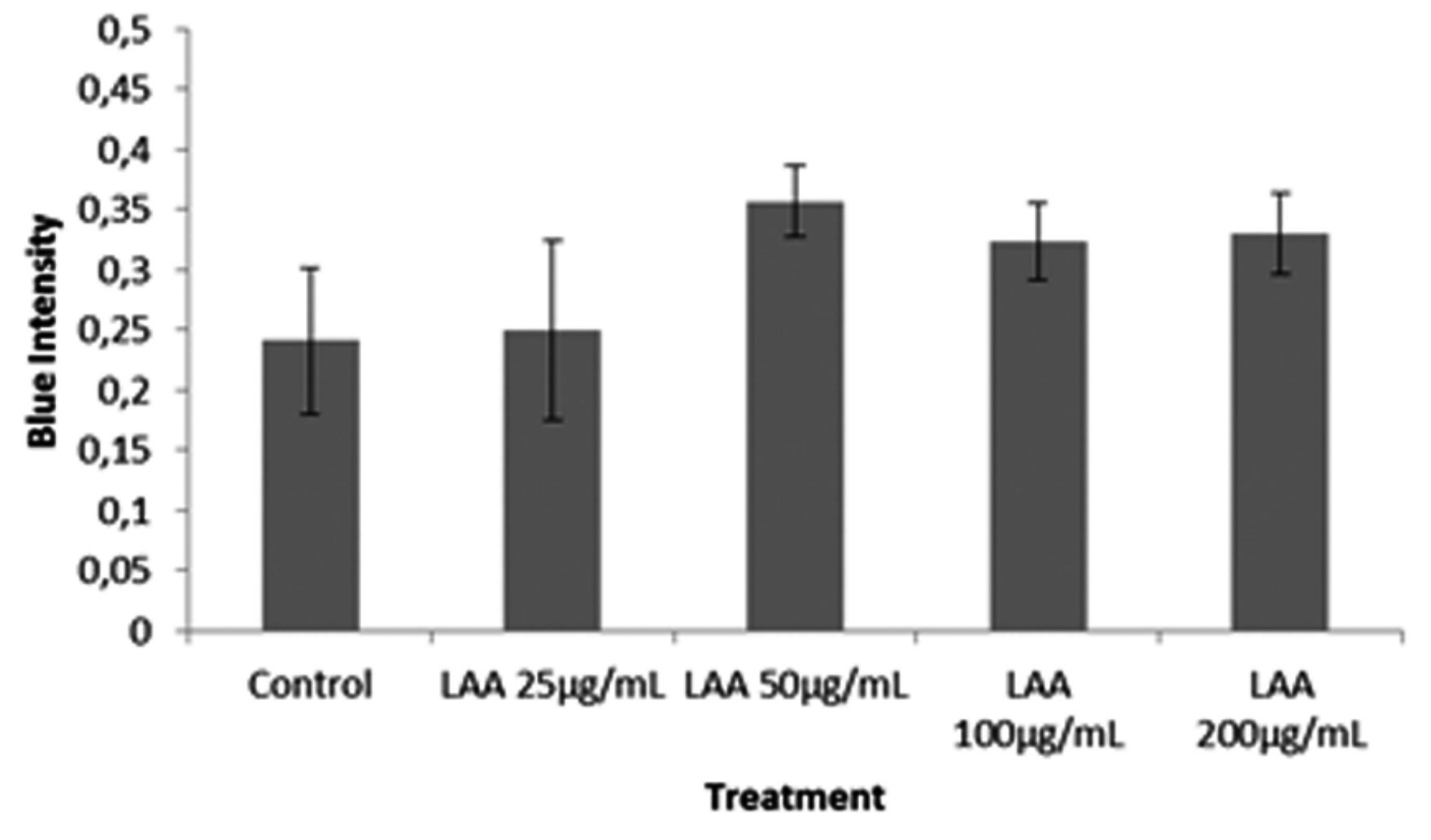


Figure 11

Growth curve of ADSC in various Platelet Rich Plasma (PRP) concentration of medium.

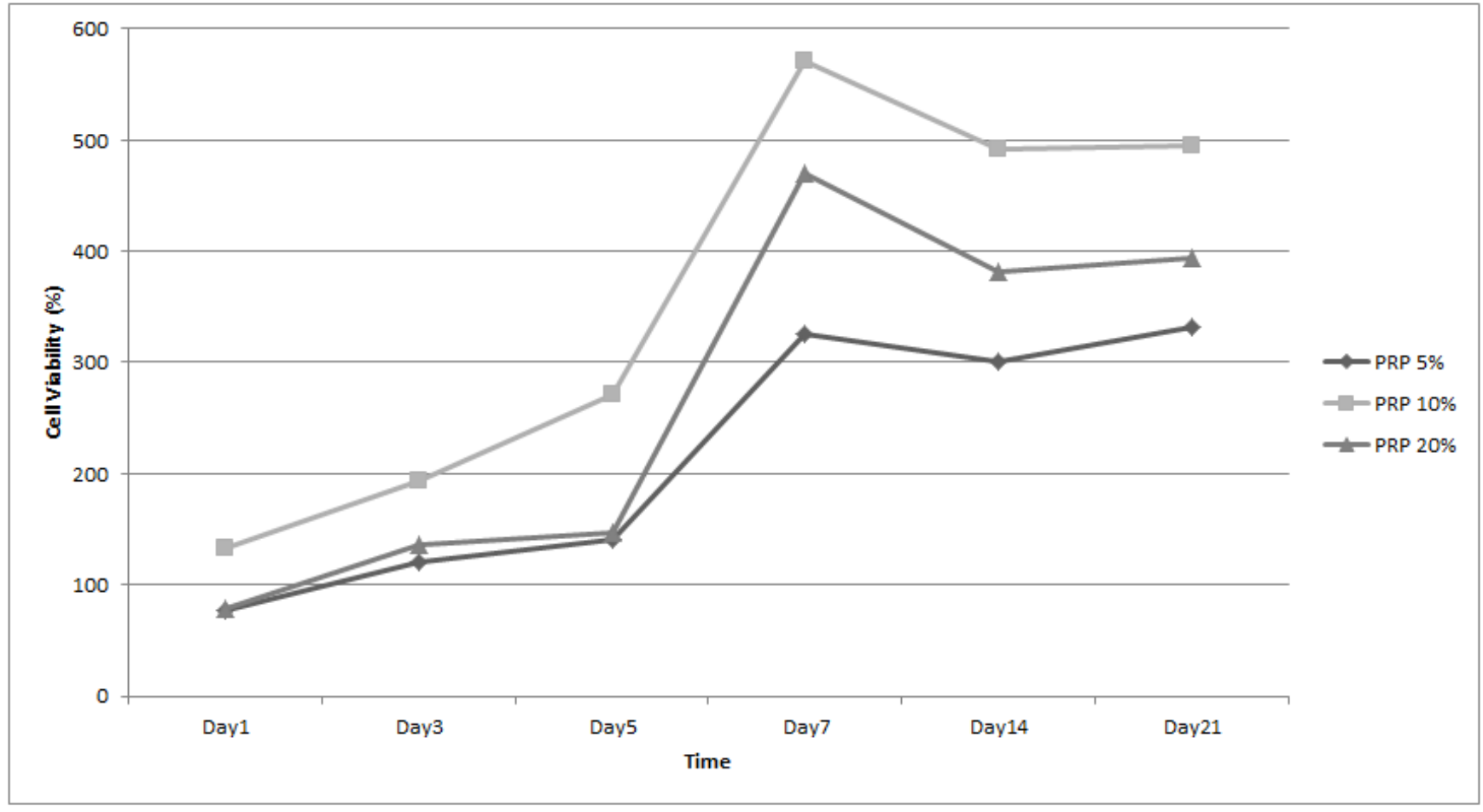


Figure 12

Graph of Blue Colour Intensity Comparison from Alcian Blue Staining in Various PRP Concentrations

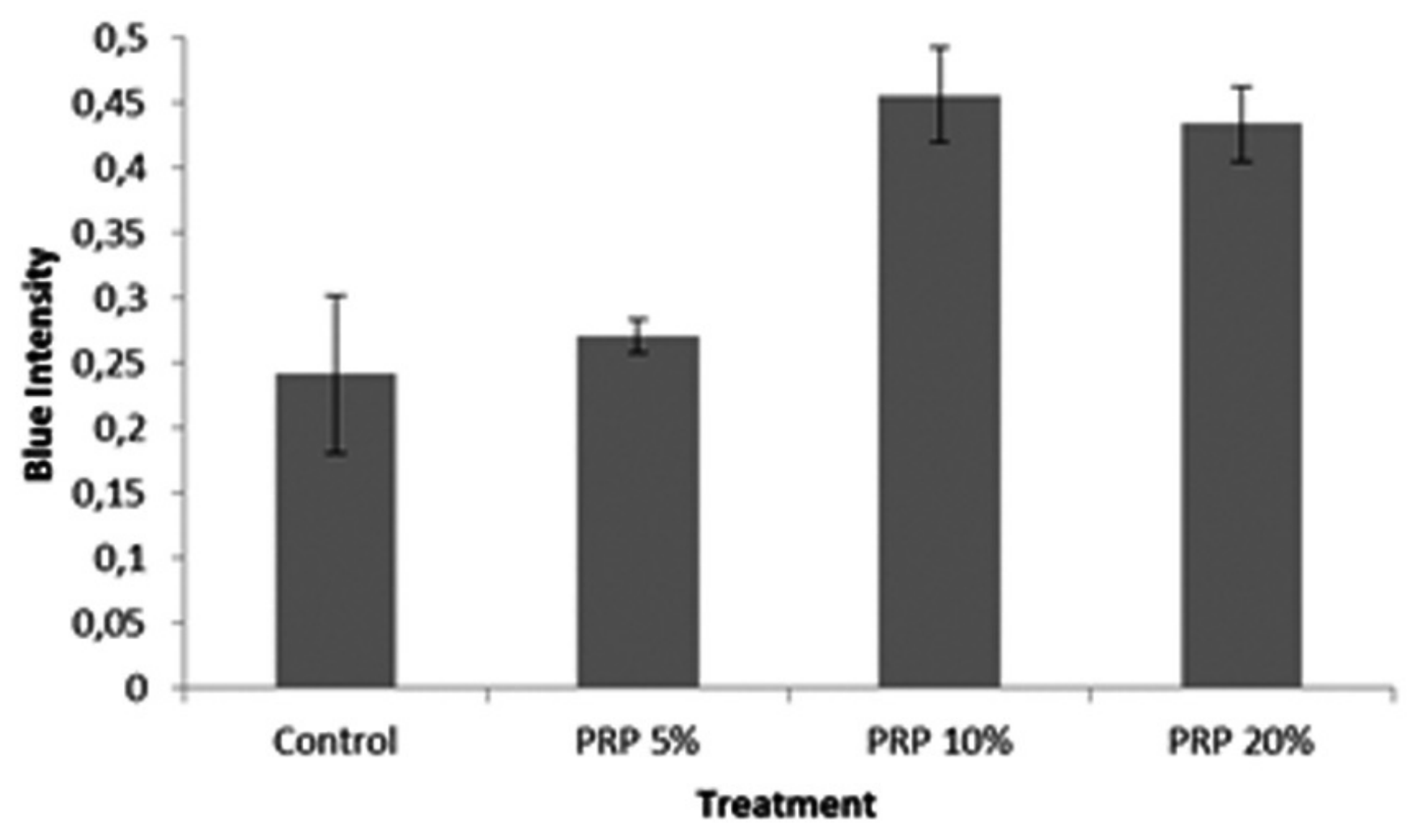




\section{Figure 13}

Graph of glycosaminoglycan (GAG) content in ADSC cultured on scaffold in $50 \mu \mathrm{g} / \mathrm{mL}$ LAA and $10 \%$ PRP supplemented medium

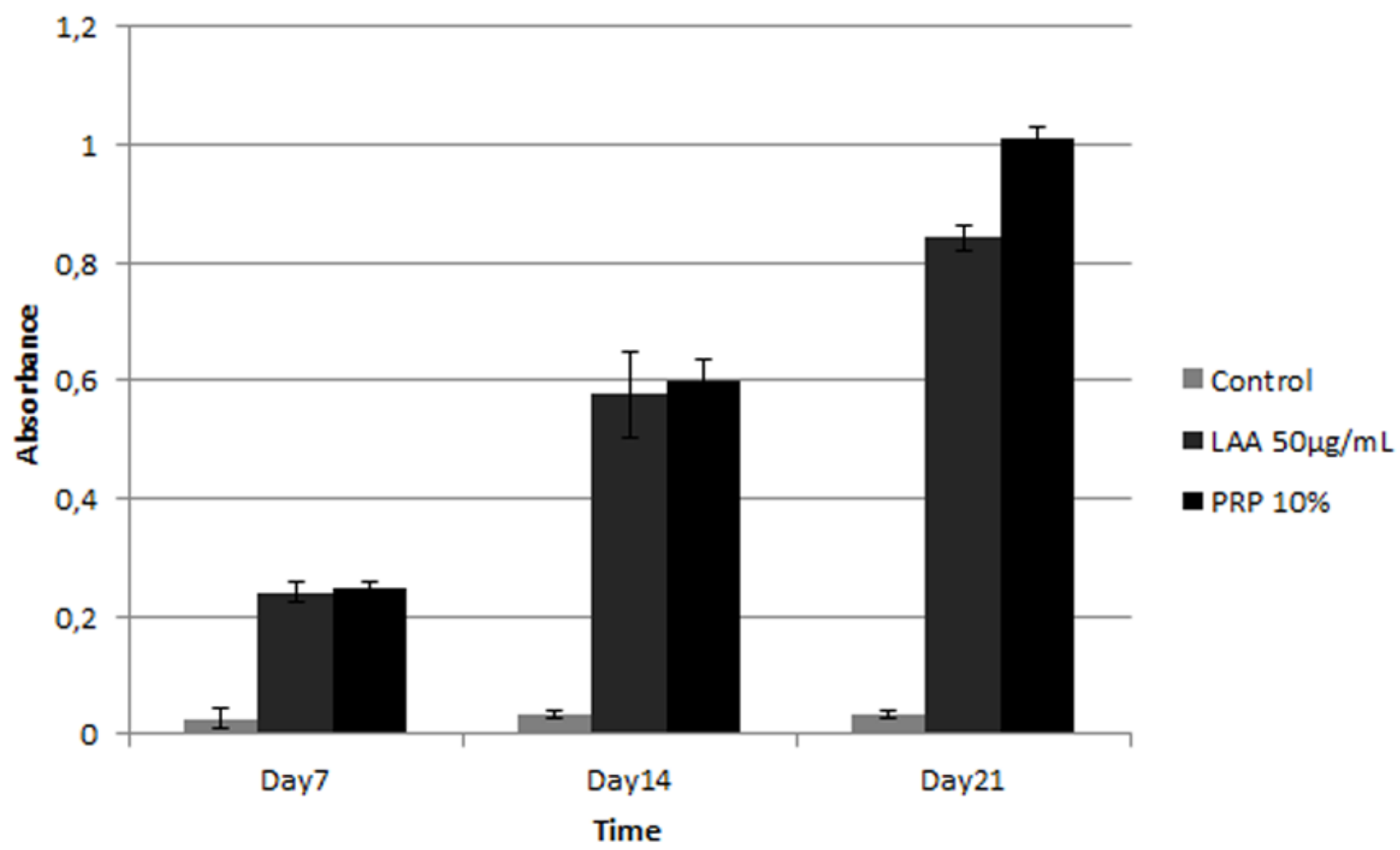

